d https://doi.org/10.31869/ruhama.v4i2716 :

\title{
THE ROLE OF TEACHERS AND PARENTS IN LEARNING AKHLAK DURING THE COVID- 19 PANDEMIC IN MTSN 2 PASAMAN: CASE STUDY OF LEARNERS' LEARNING INTERESTS
}

\author{
Maimun, Ahmad Lahmi, Syaflin Halim \\ Universitas Muhammadiyah Sumatera Barat, Indonesia \\ maimunkamal15@gmail.com
}

\section{ARTICLE INFO}

\section{Article History:}

Received: june 5, 2021

Revised: June 25,2021

Accepted: August 08, 2021

Published: October 31, 2021

\section{*Corresponding}

Author:

ame: Maimun

Email:

maimunkamal15@gmai

1.com

Phone/WA:

081261647985

\section{ABSTRACT}

Researchers found problems in the practice of the role of teachers and parents during online learning for students. Based on these conditions, the role of teachers and parents becomes what students need during learning. Therefore, the author raised this qualitative research with the title 'The Role of Teachers and Parents in Learning Morals during the Covid-19 Pandemic at MTsN 2 Pasaman: A Case Study of Student Interest in Learning.' Problem formulation: (1) What is the role of teachers and other people? parents in online learning of morals during the covid 19 pandemic to students of MTsN 2 Pasaman? (2) What is the role of teachers and parents in fostering interest in religious learning, especially moral aqidah to students of MTsN 2 Pasaman? to students of MTsN 2 Pasaman. (2) The role of teachers and parents in cultivating interest in learning Islam, especially the moral creed towards the students of MTsN 2 Pasaman.

Research method: This study uses a descriptive qualitative approach. Descriptive research aims to make research results real, accurate, and systematic about a series of real events and characteristics of certain regions and communities. Data collection techniques apply interview, observation, and documentation methods. The results of this study were determined by the level of knowledge, the presence of parents, and interaction. So, students who have parents with religious knowledge are also good, and are more at home, then the role of parents can be given as a whole in learning morals. On the other hand, students who have parents with less knowledge or religious knowledge, and are busy working, have a limited role in learning activities for their children's morals and beliefs. Parents provide motivation, messages, advice, sanctions (punishments) and rewards (rewards) to their children. This is done to foster interest in learning the religion of their children who study at school or at home. Therefore, parents have performed their roles as motivators, educators, discipline enforcers, and regulators or controllers. All of these roles are carried out differently for each parent, depending on the level of knowledge and religious basis, as well as the intensity of the meeting between parents and children in interacting while at home. 
Abstrak

Peneliti menemukan masalah pada praktik peran guru dan orang tua selama pembelajaran dalam jaringan (daring) bagi peserta didik. Berdasarkan pada kondisi tersebut, peran guru dan orang tua menjadi hal yang dibutuhkan peserta didik selama pembelajaran. Maka dari itu, penulis mengangkat penelitian kualitatif ini dengan judul ` Peran Guru dan Orang Tua Dalam Pembelajaran Akidah Akhlak Saat Pandemi Covid-19 Di MTsN 2 Pasaman: Studi Kasus Minat Belajar Peserta Didik. 'Rumusan masalah: (1) Bagaimana peran guru dan orang tua dalam pembelajaran daring akidah akhlak selama pandemi covid 19 terhadap peserta didik MTsN 2 Pasaman? (2) Bagaimana peran guru dan orang tua dalam menumbuhkan minat belajar agama, khususnya akidah akhlak terhadao peserta didik MTsN 2 Pasaman? Tujuan pada penelitian ini yaitu untuk mengetahui: (1) Peran guru dan orang tua dalam pembelajaran daring akidah akhlak selama pandemi covid 19 terhadap peserta didik MTsN 2 Pasaman. (2) Peran guru dan orang tua dalam menumbuhkan minat belajar agama Islam, khususnya akidah akhlak terhadap peserta didik MTsN 2 Pasaman.Metode penelitian: Penelitian ini menggunakan pendekatan kualitatif deskriptif. Penelitian deskriptif bertujuan untuk membuat hasil penelitian secara nyata, akurat, dan sistematis tentang rangkaian kejadian nyata dan karakteristik daerah dan masyarakat tertentu Teknik pengumpulan data menerapkan metode wawancara, observasi, dan dokumentasi. Hasil penelitian ini ditentukan oleh tingkat pengetahuan, keberadaan orang tua, dan interaksi. Jadi, siswa yang memiliki orang tua dengan wawasan pengetahuan agama juga baik, dan berada lebih banyak di rumah, maka peran orang tua dapat diberikan secara utuh dalam pembelajaran akidah akhlak. Sebaliknya, siswa yang memiliki orang tua dengan wawasan pengetahuan atau keilmuan agamanya kurang, serta sibuk bekerja, maka peran terhadap kegiatan belajar akidah akhlak anaknya juga terbatas. Orang tua memberikan motivasi, pesan, nasehat, sanksi (punishment) dan penghargaan (reward) kepada anaknya. Hal ini dilakukan untuk menumbuhkan minat belajar agama anaknya yang belajar di sekolah maupun di rumah. Oleh karena itu, orang tua telah melakukan perannya sebagai motivator, pendidik, penegak disiplin, serta pengatur atau pengontrol. Segenap peran tersebut dilakukan berbedabeda setiap orang tua, tergantung tingkat pengetahuan dan dasar agama, serta intensitas pertemuan orang tua tua dan anak dalam berinteraksi selama di rumah.

Kata Kunci $\quad$ Peran orang tua dan guru, pembelajaran akidah akhlak

\section{INTRODUCTION}

Suasana pembelajaran kolaboratif berguna untuk menciptakan pembelajaran yang terpadu (Warni et al., 2021), sehingga peserta didik memiliki keinginan dan semangat yang tinggi untuk belajar, baik di rumah maupun di madrasah (Ritonga et al., 2021; Sartika et al., 2020). Minat dapat didefenisikan dengan rasa suka, tertarik, atensi, fokus, tekun, pengetahuan serta keterampilan (Harackiewicz et al., 2016). Minat juga menjadi dasar yang krusial untuk seseorang dalam beraktivitas dengan baik. Sebagai aspek psikologis, minat tidak hanya memengaruhi perilaku seseorang, tetapi juga menggugah semangat seserang untuk terus melakukan dan mendapatkan sesuatu (Johnson, 2017).

Dalam Alquran juga telah diserukan secara tegas tentang orang-orang yang berilmu ini, yakni terdapat dalam surat Al-Mujadilah ayat 11. Ayat tersebut memuat keutamaan orang-orang beriman dan berilmu pengetahuan bahwa mereka adalah orang yang mendapatkan kemualiaan melalui diangkatkan derajatnya dari orang-orang lainnya. Sehingga menjadi peserta didik yang beriman serta berilmu pengatahuan juga menjadi salah satu bagian dari golongan ini. Hal ini tentu saja didukung oleh adanya kehadiran peran orang tua dan guru dalam pelaksanaan pembelajaran secara efektif dan berkelanjutan.

Orang tua merupakan salah satu faktor yang dapat memengaruhi minat seseorang. Faktor-faktor yang dapat memengaruhi minat seseorang khususnya pembentukan minat 
belajar antara lain teman sepermainan, pola asuh orang tua, dan relasi (Azhar et al., 2020). Selanjutnya, supaya minat belajar agama peserta didik di madrasah baik, maka diperlukan upaya yang konkret oleh orang tua. Upaya yang dimaksud tersebut adalah orang tua sebagai penanggung jawab utama dalam pendidikan dalam mengontrol proses belajar anaknya di rumah.

Dengan kata lain, peran orang tua dalam mengawasi dan mengendalikan kegiatan belajar agama Islam anaknya adalah faktor penting yang membawa keberhasilan seorang anak dalam belajar agama Islam. Salah satu kiat pembelajaran yang dilaksanakan satuan pendidikan saat ini yakni melalui pembelajaran dalam jaringan (daring) dan luar jaringan (luring) (Coman et al., 2020). Hal ini bermula dari adanya wabah virus corona virus disease 19 (covid 19). Demi kepentingan pelaksanaan pembelajaran tersebut, guru dan orang tuasemestinya mampu bertindak sebagai fasilitator dan kontributor sesuai kemampuan dan bidang keahlian yang dimiliki. Sebagai guru, tentu saja memiliki peran yang tidak terbatas dalam hal pemberian informasi pembelajaran yang bermakna pada peserta didik.

Salah satu peran guru tersebut yakni melaksanakan pembelajaran berbasis bahan ajar. Bahan ajar yang disiapkan guru tersebut didistribusikan kepada peserta didik untuk dipelajari dan dipahami para peserta didik di rumah masing-masing. Pada sisi yang lebih kreatif dan inovatif, sebagian guru melakukan pembelajaran online dengan memanfaatkan aplikasi pembelajaran yang telah tersedia di perangkat android, baik smartphone maupun komputer (Suparman et al., 2020).

Selama pandemi covid 19 ini, pembelajaran karakter peserta didik perlu memperoleh perhatian lebih dari guru serta orang tua (Suwarno et al., 2021), karena intensitas pertemuan tatap muka guru dan pendidik sangat terbatas (Akmal \& Ritonga, 2020). Sementara itu, setiap materi dalam palajaran akidah akhlak menuntut peserta didik mahir membaca ayat-ayat Alquran, hadits, dan penerapan karakter dalam kehidupan sehari-hari. Berdasarkan pengamatan (observasi) terhadap peserta didik, selanjutnya berdasarkan wawancara dengan guru akidah akhlak di MTsN 2 Pasaman, guru belum sepenuhnya melaksanakan pembelajaran daring dan luring secara maksimal selama masa pendemi covid 19 ini. Guru menggunakan aplikasi whatsapp grup kelas untuk pembelajaran daring.

Oleh karena kendala yang terdapat dalam proses pembelajaran daring dan luring tersebut, maka dapat berdampak pada peserta didik, sehingga kurang berminat dan termotivasi dalam belajar. Hasilnya, peserta didik kurang memahami materi yang dipelajari. Padahal, materi akidah akhlak merupakan materi pokok yang sangat penting dalam pelaksanaan pendidikan di madrasah. Melalui pembelajaran akidah akhlak secara daring dan luring inilah guru dan peserta didik akan lebih mudah terbantu dan mudah melaksanakan pembelajaran dengan harapan peserta didik memiliki pemahaman yang cukup dan kepribadian berkarakter Islami (Andria Rosa et al., 2020).

Pada saat peneliti melaksanakan observasi ke MTsN 2 Pasaman, terdapat masalah yang penulis temukan selama pembelajaran yakni perlu peningkatan peran orang tua dan guru dalam pelaksanaan pembelajaran daring dan luring, yang mana dapat berefek terhadap pemahaman, minat, dan penerapan pembelajaran akidah akhlak peserta didik di rumah masing-masing. Selanjutnya, peneliti tertarik melakukan pengamatan lebih lanjut di MTsN 2 Pasaman Kecamatan Rao Kabupaten Pasaman. Dari hasil observasi tersebut, peneliti meyimpulkan bahwa banyak peserta didik yang kurang 
berminat belajar agama, khususnya mata pelajaran akidah akhlak. Untuk itu, penulis mengangkat penelitian kualitatif ini dengan judul 'Peran Guru dan Orang Tua dalam Pembelajaran Akidah Akhlak Saat Pandemi Covid-19 Di MTsN 2 Pasaman: Studi Kasus Minat Belajar Peserta Didik.

\section{METHOD}

Penelitian ini dilaksanakan dengan menggunakan pendekatan kualitatif. Metode yang dipilih adalah dengan metode deskriptif. Dalam pemaparan konsep dari Bogdan dan Taylor, bahwa kualitatif adalah tahapan dari penelitian untuk dapat memperoleh data berupa deskripsi seperti data yang berbentuk kata-kata, berupa tulisan dan atau lisan berdasarkan perilaku yang diamati oleh peneliti (Smit \& Onwuegbuzie, 2018). Sementara itu, dalam sumber lain juga menjelaskan bahwa metode deskriptif adalah suatu metode yang meneliti suatu kelompok, misalnya suatu objek, manusia, suatu keadaan atau pun kondisi, dan suatu pemikiran yang ada pada saat ini (Kim et al., 2017).

Kemudian, metode deskripsi bertujuan untuk memberikan sebuah deskripsi atau gambaran maupun penjelasan secara terstruktur dan sistematis terkait dengan peristiwa yang diamati. Selanjutnya, karena penelitian kualitatif menggunakan latar alamiah, maka desain penelitian ini menggunakan desain pendekatan naturalistik. Pendekatan ini menekankan pada pencarian dan penemuan pemahaman dan pengertian seputar fenomena di suatu latar dalam konteks khusus (Mohajan, 2018).

Peneliti menggunakan pendekatan naturalistik ini mempertimbangkan bahwa dalam pendekatan ini lebih meneliti terhadap pemahaman suatu fenomena di suatu latar atau daerah yang khusus. Sehingga penelitian ini diharapkan dapat memaparkan peran orang tua dan guru dalam melaksanakan pembelajaran akidah akhlak di MTsN 2 Pasaman Kecamatan Rao Kabupaten Pasaman. Dalam pelaksanaannya, peneliti mencari data yang sebenarnya dari hasil penelitian di lapangan. Selanjutnya, data itu dikumpukan dan diolah untuk dibuatkan ke dalan hasil penelitian pada hasil dan pembahasan.

Bentuk penyajiannya ini secara deskriptif, yakni menggambarkan atau mendeskripsikan peristiwa dan kejadian yang ada. Peristiwa itu bisa berupa rekayasa manusia, maupun bersifat ilmiah. Kajian pada penelitian ini berbentuk kajian aktivitas, ciri khas, perubahan, interaksi, persamaan dan perbedaannya pada peristiwa lain. Penelitian deskriptif bertujuan untuk membuat hasil penelitian secara nyata, akurat, dan sistematis tentang rangkaian kejadian nyata dan karakteristik daerah dan masyarakat tertentu (Williams, 2007). Penelitian ini dilakukan di MTsN 2 Pasaman Kecamatan Rao Kabupaten Pasaman Madrasah ini terletak di Jalan Medan-Padang, Desa Kubu Cotu, di jalan lintas Sumatra.Pelaksanaan penelitian ini dilaksanakan dari bulan Januari-Maret 2021. Desain penelitian berupa penelitian kualitatif dengan desain penelitian deskriptif korelasional. Jumlah populasi yang diamati adalah peserta didik di di MTsN 2 Pasaman. Peneliti memilih kelas sampel dengan penggunaan smartphone terbanyak yakni kelas IX-7 sebanyak 33 peserta didik dari 36 peserta didik.

Subjek penelitian ini yakni orang tua, guru, kepala madrasah, dan tata usaha. Selanjutnya objek pada penelitian ini yakni tentang peranan orang tua dan guru dalam meningkatkan mutu pendidikan di Madrasah Tsanawiyah Negeri 2 Pasaman Kecamatan Rao Kabupaten Pasaman. Teknik non tes yang dilakukan secara sistematis adalah teknik yang digunakan peneliti dalam pengunpulan data. Prosedur pengumpulan data diambil dari data yang sesuai dengan persoalan yang diteliti. Oleh karena itu, dalam rangka mengetahui bagaimana upaya yang dilakukan orang tua dan guru sebagai pembimbing 
anak selama mengikuti pembelajaran di rumah atau daring, peneliti melaksanakan suatu penelitian yang pada pelaksanaannya menggunakan teknik pengumpulan data hasil pengamatan atau observasi, wawancara, dokumentasi, serta studi dokumenter. Pengumpulan data yang didapatkan dari penelitian ini dalam bentuk data wawancara dan dilaksanakan pengolahan data. Tahap awal peneliti melakukan telaah terhadap seluruh data yang diperoleh dari beragam sumber, diantaranya foto, gambar, dokumen resmi, angket, dan sebagainya. Sesuai dengan penjelasan tentang data tersebut, dapat dijelaskan bahwa semua data yang didapatkan itu dibaca, dipelajari, dan ditelaah. Pada tahap lanjut, dilakukan reduksi data, penyajian data, dan menarik kesimpulan.Prosedur analisis dataini dengan membuat data yang dikumpulkan untuk diolah sesuai dengan tujuan peneliti. Seluruh data yang telah terkumpul dari lapangan itu yang akan dianalisis secara kelesuruhan.

\section{RESULTS\&DISCUSSION}

Temuan Penelitian pada penelitian ini yakni peran orang tua dalam pembelajaran akidah akhlak di MTsN 2 Pasaman. Cakupan mengenai peran orang tua ini termasuk temuan yang kompleks. Artinya, berdasarkan data orang tua peserta didik dari lintas wawasan, profesi dan pengetahuan, maka peneliti membuat kelompok klasifikasi agar lebih mudah dikenali dan diindentifikasi. Klasifikasi tersebut peneliti dapatkan sesuai dengan hasil pengamatan (observasi) peneliti di MTsN 2 Pasaman. Peserta didik dengan orang tua yang berpengatahuan akidah akhlak dan berada di rumah.

Orang tua pada kelompok ini merupakan kelompok yang senantiasa memperhatikan aktivitas anaknya saat berada di rumah. Hal ini disebabkan karena mereka memiliki kesempatan dan waktu yang cukup banyak dalam mendampingi anaknya belajar di rumah. Keterangan ini didukung oleh pengakuan orang tua saat wawancara, yakni orang tua dari peserta didik yang berhasil memberikan keteladanan melalui penerapan akhlak yang baik kepada anaknya (Khairunnas et al., 2021). Kebiasaan yang terus dilakukan anaknya yaitu membaca bismillah sebelum makan dan mengenakan pakaian yang rapi dan sopan, selalu terlebih dahulu mencium tangan orang tua sebelum berangkat ke madrasah. Peserta didik dengan kategori orang tua yangmemiliki pengetahuan atau dasar agama terbatas dan lebih sibuk bekerja.

Dalam hal ini terdapat peserta didik yang memiliki orang tua dengan pengetahuan atau dasar agama yang terbatas (kurang) dan kesibukan bekerja sehari-hari. Berdasarkan hasil pengamatan yang peneliti dapatkan, orang tua ini cukup sibuk dalam bekerja, sehingga kurang berinteraksi dengan anaknya dan tidak dapat memberikan bantuan kepada anaknya secara utuh dalam menyelesaikan tugas dari orang tuanya, khususnya pada mata pelajaran akidah akhlak. Kondisi ini didukung oleh hasil wawancara yang peneliti lakukan bersama orang tua dari peserta didik pula.

Peran orang tua untuk menumbuhkan minat belajar akidah akhlak di MTsN 2 Pasaman. Ditekankan pada aspek perilku peserta didik terhadap aktivitas belajarnya, di antaranya dibagi berdasarkan tingkat antusiasme (mengikuti aktivitas belajar dengan penuh semangat) khususnya mata pelajaran akidah akhlak. Selanjutnya, peneliti memilih kelas dengan kriteria pengguna pembelajaran daring terbanyak di kelas 9 yaki kelas 97 dengan jumlah peserta didik sebanya 38 orang. Dari data tersebut, ditemukan seluruh peserta didik yang menyukai mata pelajaran akidah akhlak. Kemudian, pengamatan peneliti berlanjut dengan mengamati orang tua mata pelajaran akidah akhlak yang masuk

Maimun; Lahmi, Ahmad; Halim, Syaflin (2021). The Role of Teachers And Parents In Learning Akhlak During The Covid-19 Pandemic In MTsN 2 Pasaman: Case Study Of Learners' Learning Interests Ruhama :Islamic Education Journal, Vol. 4, (No. 2), pp. 111-122 DOI: https://doi.org/10.31869/ruhama.v4i2716 
ke kelas untuk melakukan pembelajaran bersama peserta didik. Seluruh peserta didik menyinak dan memahami materi yang disampaikan guru akidah akhlak di MTsN 2 Pasaman. Peserta didik yang memiliki orang tua berpengetahuan agama yang baik dan berada di rumah diperoleh data bahwa mereka selalu memperhatikan anaknya dengan bertanya kepada anaknya sepulang sekolah. Misalnya, bertanya tentang kegiatan belajar di sekolah dan menilik buku pelajaran khususnya agama (akidah akhlak) anak (Yusuf et al., 2020).

Orang tua juga menyempatkan untuk melakukan pendampingan dan pengawasan saat anaknya belajar di rumah, baik dengan melihat buku catatan dan latihan maupun pada buku paket dan buku cetaknya. Selain itu, apabila ada pertanyaan yang anaknya kurang mengerti atau sulit dipahami atau dikerjakan, maka orang tua tersebut turut serta memberikan bantuan sebisa mungkin dalam memberikan solusi dalam mengerjakan tugas anaknya. Bahkan, sebagai bentuk dukungan terhadap ketuntasan belajar anaknya, orang tua juga mencarikan orang tua les tambahan untuk menambah pemahaman agamanya, baik hafalan maupun wawasan pendidikannya.

Berdasarkan pengakuan orang tua dalam wawancara dengan peneliti, orang tua pada kategori ini untuk menanamkan minat belajar agama kepada anaknya, orang tua akan memberikan dorongan atau dukungan dan menyemangati anaknya secara langsung agar minat belajarnya dapat tumbuh dan berkembang dengan baik. Berdasarkan pengakuan orang tua dalam wawancara yang dilakukan oleh peneliti, orang tua pada kategori ini akan mendorong dan memotivasi seta menyemangati anaknya secara langsung dalam rangka menumbuhkan minat belajar agama pada diri sang anak.

Peserta didik yang memiliki orang tua berpengetahuan agama yang kurang dan sibuk bekerja diperoleh hasil bahwa mereka mengakui adanya keterbatasan komunikasi kurang, sehingga antara orang tua dan anak juga kurang saling mengetahui aktivitas dan perilaku anaknya selama belajar di rumah. Sehingga, ketika suatu kali anaknya menanyakan tugasnya yang terbilang sulit, maka orang tua meminta bantuan istrinya atau malah menyuruh belajar dengan teman lain yang rumahnya tak jauh dari rumahnya. Hal ini terjadi dikarenakan orang tua memiliki kesibukan lain yakni sibuk bekerja di luar rumah.

Dari keterangan wawancara yang peneliti dapatkan pada kategori orang tua seperti ini dalam menumbuhkan minat belajarnya, maka diberikan arahan dan nasehat untuk terus membuat anaknya berminat dalam belajar. Berikut ini merupakan ungkapan beberapa arahan yang diberikan orang tua dari peserta didik Dari segi orang tua, peneliti mendapatkan keterangan dari orang tua mata pelajaran akidah akhlak, bahwa dalam pembelajaran di kelas, terjadi suasana belajar yang aktif. Hal ini karena orang tua menerapkan berbagai metode pembelajaran yang bervariasi yang membuat peserta didik mampu memahami materi dengan baik.Hal ini didukung oleh hasil wawancara peneliti dengan guru akidah akhlak menerangkan bahwa semuanya disesuaikan dengan kebutuhan materi dan peserta didik agar tercipta suasana yang aktif, efektif, dan menyenangkan.

Hasil penelitian tentang peran orang tua dan orang tua dalam menumbuhkan minat belajar akidah akhlak peserta didik yakni (1) Orang tua sebagai pemberi dorongan (motivator). Setelah melakukan observasi secara langsung ke lapangan, maka peneliti menemukan orang tua yang senantiasa perhatian kepada anaknya, dengan cara menanyakan tentang kegiatan belajar anaknya di madrasah. Selain itu, orang tua juga menyempatkan untuk melakukan pendampingan dan pengawasan pada anaknya dalam belajar dan mengerjakan tugas di rumah. Motivasi yang diberikan dalam bentuk lain 
adalah ketika anaknya bertanya tentang tugas yang terbilang sulit atau tidak bisa dimengerti.

Maka orang tua tersebut tidak sungkan-sungkan untuk langsung membantu anaknya dalam mengerjakan pekerjaan rumah (PR) atau tugas yang diberikan orang tua. Dalam hasil wawancara di atas, peneliti mendapatkan orang tua yang semacam ini memaksimalkan perannya dengan menumbuhkan minat belajar anaknya melalui upayaupaya yang bervariasi dalam menumbuhkan minat belajar akidah akhlak ankanya. Salah satunya dengan mendukung, memotivasi, dan menyemangati anaknya untuk menciptakan minat belajarnya. (2) Orang tua sebagai pemberi perhatian belajar (pendidik) .Berdasarkan hasil pengamatan yang telah dilakukan, peneliti menemukan informasi bahwa orang tua mereka selalu menanyakan tentang kegiatan pembelajaran akidah akhlak di madrasah.

Selain itu, orang tua menyempatkan memeriksa buku pelajaran dan bahan ajar anaknya sepulang dari madrasah. Setelah diketahui demikian, orang dengan peran semacam inilah yang berhasil dalam menumbuhkan minat belajar akidah akhlak anaknya. Secara tidak langsung ia telah menjalankan perannya sebagai pendidik di rumah bagi anaknya. (3) Orang tua sebagai pemberi peringatan (penegak disiplin). Berdasarkan pengamatan yang telah dilakukan oleh peneliti, didapatkan informasi bahwa orang tua yang selalu menanamkan sifat kedisiplinan yang teratur dan berkelanjutan dalam belajar, memberikan pengaruh yang baik terhadap minat belajar anaknya. Beberapa contohnya yakni menjadwalkan waktu untuk belajar anaknya dan belajar tambahan di luar belajar bersama orang tua. Keteladanan dan kedisiplinan dalam hal ini mampu menumbuhkan minat belajar agama (akidah akhlak) anaknya sebagai penegak disiplin (Kasno \& Harianto, 2019), karena orang tua telah memberikan contoh dalam bertutur kata, bersikap, dan berbuat dalam kelas maupun di rumah. Sehingga dapat terbiasa saat peserta didik berada di luar kelas dan lingkungan sekitar. (4) Orang tua sebagai pengawas (pengontrol) (Nurjanah, 2020).

Berdasarkan hasil pengamatan yang peneliti temukan, diperoleh informasi pula bahwa orang tua yang selalu mengawasi kegiatan belajar anaknya di rumah dan di sekolah, dapat membantu pelaksanaan perannya sebagai pengontorl atau pengawas dalam kegiatan belajar akidah akhlak anaknya di rumah. Beberapa contohnya yakni orang tua selalu memperhatikan pekembangan belajar agama anaknya terhadap orang tua mata pelajaran agama di sekolah. Dengan adanya pengawasan yang berkelanjutan sepertin ini, orang tua dapat mengetahui seberapa peningkatan belajar anaknya. Hasil penelitian tentang peran guru dalam menumbuhkan minat belajar akidah akhlak di MTsN 2 Pasaman yakni secara umum, peranan guru sebagai pendidik meliputi tiga belas macam yakni sebagai pengoreksi, penginspirasi, narasumber, pengorganisasi, pemotivasi, pemrakarsa, penyedia sarana, pembimbing, pemeraga, pengelola kelas, perantara, penyelia, dan pengevaluasi. Secara umum, orang tua akidah akhlak telah melaksanakan semua peran tersebut sebagai pendidik dengan baik.

Pembahasan penelitian ini mengacu pada peranan orang tua dalam pembelajaran akidah akhlak di MTsN 2 Pasaman, yakni pada prinsipnya, setiap orang tua telah melakuan perannya sesuai kemampuan dan kondisi keluarga masing-masing. Artinya, berbagai peran telah dilaksanakan orang tua sebagai pendamping dan pembimbing kegiatan belajar akidah akhlak anaknya di rumah secara daring. Beberapa orang tua telah berhasil melakukan perannya secara utuh, mengingat dan memperhatikan orang tuanya banyak mengahbiskan waktu di rumah serta memiliki wawasan yang lebih luas tentang

Maimun; Lahmi, Ahmad; Halim, Syaflin (2021). The Role of Teachers And Parents In Learning Akhlak During The Covid-19 Pandemic In MTsN 2 Pasaman: Case Study Of Learners' Learning Interests Ruhama :Islamic Education Journal, Vol. 4, (No. 2), pp. 111-122 DOI: https://doi.org/10.31869/ruhama.v4i2716 
agama. Maka dari itu, mereka dapat mengawasi dan memberikan pemahaman yang lebih baik kepada anaknyadengan mudah, meskipun pembelajaran dilakukan secara daring.

Selain itu, ada pula orang tua yang kurang dalam melaksanakan perannya. Penyebab utama yang membuat peran tersebut kurang terlaksana secara utuh ada beberapa hal. Kondisi tersebut memberikan dampak yang cukup besar pada kegiatan pembelajaran agama (akidah akhlak) peserta didik di kelas maupun di lingkungan lainnya (Syamsir, 2017). Orang tua yang melaksanakna perannya secara baik dalam pelaksanaan kegiatan pembelajaran agama, maka saat di dalam kelas anaknya mampu bertutur kata, bersikap, atau berakhlak lebih sopan santun dan menghormati serta menghargai temannya yang lain.

Sementara itu, peran orang tua yang tidak dilaksanakan perannya secaramaksimal, akan dapat memengaruhi minat belajar pada anaknya. Misalnya antusias anak dalam pembelajaran menjadi berkurang, baik pembelajaran di dalam maupun di luar kelas. Secara sikap, maka jelas sudah si anak dalam bersikap dengan sesuka hati, karena keterbatasan wawasan dan bersikap secara santun di dalam kehidupan kelas dan luar kelas.

Setelah menguraikan hasil penelitian di atas, maka peneliti mendapatkan informasi penting bahwa setiap orang tua mempunyai strategi atau pun cara tersendiri dan bervariasi dalam menumbuhkan minat belajar agama anaknya di rumah. Beberapa cara tersebut di antaranya memberikan kalimat-kalimat motivasi yang bertujuan memberikan nasehat kepada anaknya supaya lebih meningkatkan cara belajarnya, khususnya pada mata pelajaran PAI (akidah akhlak) (Ruhaningsih, 2011)

Selain motivasi seperti contoh di atas, ada lagi orang tua yang memberikan ungkapan nasehat terbaik mereka kepada anaknya dalam rangka memberikan arahan dan peneguran kepada anaknya yang bermalas-malasan belajar atau mengerjakan tugas. Beberpa di antara orang tua juga memberikan apresisasi berupa pujian saat anaknya mendapatkan nilai bagus, atau meraih prestasi di kelas. Juga apresiasi dalam bentuk bermacam-macam yang diberikan orang tua kepada anaknya, misalnya dibelikan ponsel android untuk meningkatkan minat belajar secara daring.

Peran orang tua dalam pembelajaran akidah akhlak di MTsN 2 Pasaman yakni Pada prinsipnya, setiap orang tua telah melakuan perannya sesuai kemampuan dan kondisi keluarga masing-masing. Ada yang mengunakan media pembelajaran yang menarik dan ada pula yang hanya menggunakan metode klasik saja. Sehingga ada dua suasana belajar, yakni menarik dan monoton. Artinya, berbagai peran telah dilaksanakan orang tua dalam mendampingi dan membimbing kegiatan belajar akidah akhlak anaknya di rumah secara daring. Beberapa orang tua telah berhasil melakukan perannya secara utuh, mengingat dan memperhatikan orang tuanya banyak menghabisakan waktu di rumah dan memiliki wawasan yang lebih luas tentang agama. Maka dari itu, mereka dapat dengan mudah mengawasi dan memberikan pemahaman yang lebih pula kepada anaknya, meskipun pembelajaran dilakukan secara daring. Selain itu, ada pula orang tua yang kurang dalam melaksanakan perannya.

Penyebab utama yang membuat peran tersebut kurang terlaksana secara utuh ada beberapa hal. Kondisi tersebut memberikan dampak pada kegiatan pembelajaran agama (akidah akhlak) peserta didik baik di dalam, maupun di luar kelas. Orang tua yang melaksanakna perannya secara baik dalam pelaksanaan kegiatan pembelajaran agama, maka saat berada di kelas anaknya mampu bertutur kata, bersikap, atau berakhlak lebih sopan santun dan menghargai serta menghormati teman lainnya. Sementara itu, ada pula orang tua yang dalam melaksanakan perannya dengan tidak maksimal, hal ini akan dapat 
memengaruhi minat belajar pada anaknya. Misalnya antusias anak dalam pembelajaran menjadi berkurang, baik pembelajaran di dalam maupun di luar kelasSecara sikap, maka jelas sudah si anak dalam bersikap dengan sesuka hati, karena keterbatasan wawasan dan bersikap secara santun di dalam kehidupan kelas dan luar kelas.

Peran guru dalam menumbuhkan minat belajar akidah akhlak di MTsN 2 Pasaman terlihat bahwa guru akidah akhlak selain menyampaikan materi, ia juga senantiasa memperlihatkan keteladanan dalam hal bertutur kata, bersikap, dan berbuat selama di kelas, maupun di luar kelas. Setelah menguraikan hasil penelitian di atas, maka peneliti mendapatkan informasi penting bahwa setiap orang tua mempunyai strategi atau pun cara tersendiri dan bervariasi dalam menumbuhkan minat belajar agama anaknya di rumah. Beberapa cara tersebut di antaranya memberikan kalimat-kalimat motivasi yang bertujuan memberikan nasehat kepada anaknya supaya lebih meningkatkan cara belajarnya, khususnya pada mata pelajaran PAI (akidah akhlak). Selain motivasi seperti contoh di atas, ada lagi guru yang memberikan ungkapan nasehat terbaik mereka kepada anaknya dalam rangka memberikan arahan dan peneguran kepada anaknya yang bermalas-malasan belajar atau mengerjakan tugas. Beberapa di antara orang tua juga memberikan apresisasi berupa pujian saat anaknya mendapatkan nilai bagus, atau meraih prestasi di kelas. Juga apresiasi dalam bentuk bermacam-macam yang diberikan orang tua kepada anaknya, misalnya dibelikan ponsel android untuk meningkatkan minat belajar secara daring.

\section{CONCLUSIONS}

Dari hasil dan pembahasan penelitian di atas, maka peneliti menarik suatu kesimpulan bahwa peran orang tua peserta didik di MTsN 2 Pasaman Kecamatan Rao dapat ditentukan oleh tingkat pengetahuan, keberadaan orang tua, dan interaksi. Jadi, siswa yang memiliki orang tua dengan wawasan pengetahuan yang baik atau keilmuan tentang agama juga baik, dan berada lebih banyak di rumah, maka orang tua dapat memberikan perannya secara penuh untukpembelajaran agama anak (akidah akhlak), sebab lebih sering melakukan interaksi dengan anaknya di rumah. Sebaliknya, anak-anak yang memiliki orang tua dengan wawasan atau keilmuan agama yang kurang, serta keberadaan orang tua lebih banyak di luar rumah (sibuk bekerja), maka peranan orang tua terhadap pembelajaran agama (akidah akhlak) untuk anaknya juga terbatas, sebab kesibukan orang tua yang cukup menyita waktu belajar bersama anaknya.

Pada aspek menumbuhkan minat belajar agama anaknya, masing-masing orang tua mengupayakan hal-hal yang bervariasi seperti memberikan motivasi, pesan, nasehat, sanksi (punishment) dan penghargaan (reward) kepada anaknya. Hal ini dilakukan untuk menumbuhkan minat belajar agama anaknya yang belajar di sekolah maupun di rumah. Oleh karena itu, orang tua telah melakukan perannya sebagai motivator, pendidik, penegak disiplin, serta pengatur atau pengontrol. Segenap peran tersebut dilakukan berbeda-beda setiap orang tua, tergantung tingkat pengetahuan dan dasar agama, serta intensitas pertemuan orang tua tua dan anak dalam berinteraksi selama di rumah. Oleh karena itu, minat peserta didik dipengaruhi oleh peran orang tua dan guru di madrasah.

Kesimpulan dibuat dalam bentuk paragram bukan numerik, dalam kesimpulan harus terlihat novelty dari penelitian yang telah dilakukan.

Penulisan kesimpulan tidak lebih dari $500 \mathrm{Kata}$, yang ditulis dalam times new roman, size 12 dan 1 spasi.

Maimun; Lahmi, Ahmad; Halim, Syaflin (2021). The Role of Teachers And Parents In Learning Akhlak During The Covid-19 Pandemic In MTsN 2 Pasaman: Case Study Of Learners' Learning Interests Ruhama :Islamic Education Journal, Vol. 4, (No. 2), pp. 111-122 DOI: https://doi.org/10.31869/ruhama.v4i2716 


\section{BIBILIOGRAPHY}

Akmal, R., \& Ritonga, M. (2020). Learning of Islamic Religious Education in Covid-19 Period: Analysis of Problems and Solutions for Parents. Jurnal Tarbawi, 05(02), 177-188.

Andria Rosa, Mahyudin Ritonga, \& Wedy Nasrul. (2020). Penggunaan Media Berbasis Teknologi Dalam Pembelajaran Pendidikan Agama Islam Di Sekolah Menengah Pertama Negeri. Jurnal Islamika, 3(2), 36-43. https://doi.org/10.37859/jsi.v3i2.2136

Azhar, Lahmi, A., Rasyid, A., Ritonga, M., \& Saputra, R. (2020). The Role of Parents in Forming Morality Adolescents Puberty in Globalization Era. International Journal of Future Generation Communication and Networking, 13(4), 3991-3996.

Coman, C., Tiru, L. G., Mesesan-Schmitz, L., Stanciu, C., \& Bularca, M. C. (2020). Online Teaching and Learning in Higher Education during the Coronavirus Pandemic: Students' Perspective. Sustainability, 12(10367), 1-24. https://doi.org/10.3390/su122410367

Harackiewicz, J. M., Smith, J. L., \& Priniski, S. J. (2016). Interest Matters: The Importance of Promoting Interest in Education. HHS Public Access, 3(2), 220-227. https://doi.org/10.1177/2372732216655542

Johnson, D. (2017). The Role of Teachers in Motivating Students To Learn. BU Journal of Graduate Studies in Education, 9(1), 46-49.

Kasno, \& Harianto, E. (2019). Metode Pembinaan Akhlak di SMP Muhammadiyah 2 Yogyakarta (Perspektif Psikologi Islam). PSIKOLOGIKA: Jurnal Pemikiran Dan Penelitian Psikologi, 24(1), 59-72. https://doi.org/10.20885/psikologi.vol24.iss1.art5

Khairunnas, Ritonga, M., \& Lahmi, A. (2021). Pendididkan Agama Islam sebagai Basic Kedisiplinan: Studi Fenomenologi di SMP Negeri 3 Lembah Melintang Pasaman Barat. Al-Muaddib:Jurnal Ilmu-Ilmu Sosial Dan Keislaman, 6(1), 55-65. https://doi.org/10.31604/muaddib.v5i1.55-65

Kim, H., Sefcik, J. S., \& Bradway, C. (2017). Characteristics of Qualitative Descriptive Studies: A Systematic Review. HHS Public Access, 40(1), 23-42. https://doi.org/10.1002/nur.21768

Mohajan, H. K. (2018). Qualitative Research Methodology in Social Sciences and Related Subjects. Journal of Economic Development, Environment and People, 7(01), 23-48.

Nurjanah, S. (2020). Pembentukan Akhlak Berbasis Pembiasaan Dan Keteladanan (Studi Kasus Di MAN 2 Kuningan Jawa Barat). OASIS: Jurnal Ilmiah Kajian Islam, 4(2), 55-72.

Ritonga, M., Sartika, F., \& Kustati, M. (2021). Madrasah al-Ula for Children: An Effective Learning Management in the Family during Covid-19 Pandemic. Ilkogretim Online Elementary Education Online, 20(1), 968-976. https://doi.org/10.17051/ilkonline.2021.01.97

Ruhaningsih, D. (2011). Optimalisasi Pengajaran Akhlak sebagai Upaya Mencapai Kualitas Pendidikan Berbasis Karakter (Penelitian di MAN 2 Garut). Jurnal Pendidikan Universitas Garut Fakultas Pendidikan Islam Dan Keguruan Universitas Garut, 05(01), $14-29$. 
Sartika, F., Ritonga, M., \& Rasyid, A. (2020). Implementation of Islamic Religious Education in Madrasah Ibtidaiyah During Covid-19 Pandemic. Khalifa: Journal of Islamic Education, 4(2), 97-117.

Smit, B., \& Onwuegbuzie, A. J. (2018). Observations in Qualitative Inquiry: When What You See Is Not What You See. International Journal of Qualitative Methods, 17, 1-3. https://doi.org/10.1177/1609406918816766

Suparman, Untoro, I. H. T., Suwadi, Prabowo, A., Andriyani, Humanika, E. S., Hairun, Y., \& Ritonga, M. (2020). The Implementation of Community Partnership Program to Improve the Quality of Online Learning during the Covid-19 Pandemic. Universal Journal of Educational Research, 8(11 B), 6134-6138. https://doi.org/10.13189/ujer.2020.082249

Suwarno, Durhan, \& Muhaimin. (2021). Implementation of Covid-19 on Character Education. Journal of Social Science, 2(3), 312-319.

Syamsir. (2017). Strategi Pembelajaran Guru Akidah Akhlak dalam Pembinaan Akhlak Peserta Didik di MI Al-Abrar Makassar. AL-QALAM: Jurnal Kajian \& Pendidikan, 9(1), 123-138. http://journal.iaimsinjai.ac.id/index.php/al-qalam

Warni, L., Saputra, R., \& Rasyid, A. (2021). The Use of " Rumah Belajar" in PAI Lea rning during Covid- 19 at Marhamah Elementary School. Ruhama: Islamic Education Journal, 4(1), 1-13. https://doi.org/10.31869/ruhama.v4i12618

Williams, C. (2007). Research Methods. Journal of Business \& Economic Research, 5(3), 6572.

Yusuf, M., Ritonga, M., \& Mursal. (2020). Implementasi Karakter Disiplin dalam Kurikulum 2013 Pada Bidang Studi PAI di SMA Islam Terpadu Darul Hikmah. Jurnal Tarbiyatuna, 11(1), 49-60. 
